\title{
As doenças dos mineiros de carvão do sul do Brasil em meados do século XX
}

\author{
Diseases of coal miners in southern Brazil in the \\ mid-twentieth century
}

\section{Bruno Mandelli*}

Resumo: Este artigo analisa as condições de vida e saúde dos trabalhadores das minas de carvão no sul do Brasil, em especial as doenças e enfermidades que os atingiam. Faz uma discussão sobre a emergência da saúde pública e da medicina do trabalho como áreas de estudo e pesquisa sobre as doenças que atingiam os trabalhadores, especificamente os mineiros do carvão na Europa e em alguns países da América Latina. Através da pesquisa bibliográfica de autores que pesquisaram sobre a saúde laboral dos trabalhadores e de relatórios de médicos que viveram e trabalhavam na região carbonífera naquela época, procura-se relacionar a discussão teórica com a análise empírica dos casos de acidentes e doenças dos mineiros de carvão no Brasil. Por fim, faz a análise de um processo na justiça de um acidente de trabalho de um mineiro em Santa Catarina, demonstrando os embates que ocorriam entre operários, patrões e as seguradoras de acidentes de trabalho em meados do século XX.

Palavras-chave: medicina do trabalho; doenças profissionais; mineiros de carvão.

Abstract: This article analyzes the living and health conditions of workers in coal mines in southern Brazil, especially the diseases and illnesses that affected them. It discusses the emergence of public health and occupational medicine as areas of study and research on the diseases that affected workers, specifically coal miners in Europe and in some countries in Latin America. Through the bibliographic research of authors who researched the workers' occupational health and the reports of doctors who lived and worked in the coal region at that time, the aim is to relate the theoretical discussion to the empirical analysis of the accidents

\footnotetext{
* Mestre em História pela Universidade Federal de Santa Catarina (UFSC). Doutorando em História na Universidade Federal do Rio Grande do Sul (UFRGS). ORCID: https://orcid.org/0000-0003-3584-1806. E-mail: bruno.o.mandelli@gmail.com.
} 
and diseases of coal miners in Brazil. Finally, it analyzes the lawsuit of a mining accident at work in Santa Catarina, demonstrating the clashes that occurred between workers, bosses and work accident insurers in the middle of the 20th century.

Keywords: occupational medicine; professional diseases; coal miners.

\section{Introdução}

D ESDE MEADOS DO SÉCULO XIX, quando as pesquisas sobre as condições de trabalho e de saúde da classe operária começavam a despontar, apareceram estudos sobre os mineiros em países da Europa. As transformações provocadas pelo regime fabril na vida dos trabalhadores, com o prolongamento da jornada de trabalho para até 16 horas por dia, impactaram diretamente na saúde dos operários, que tinham suas vidas ceifadas por acidentes e doenças cada vez mais constantes.

Este artigo analisa a emergência da discussão sobre medicina do trabalho, que começava a se voltar para os problemas sociais gerados pela indústria e pelo maquinismo. Tanto nos estudos teóricos em diferentes países da Europa e da América Latina quanto nos relatórios de médicos que viveram na região carbonífera no sul do Brasil e deixaram suas impressões e pesquisas acerca das doenças que acometiam os operários. Também se utilizam relatos de mineiros que contam como eram as péssimas condições de trabalho no subsolo da mineração, que desgastavam prematuramente a saúde dos jovens. Por fim, faz a análise de um processo na justiça de um acidente de trabalho de um mineiro em Santa Catarina, demonstrando os embates que ocorriam entre operários, patrões e as seguradoras de acidentes de trabalho em meados do século $X X$.

\section{Saúde pública, medicina do trabalho e as doenças dos trabalhadores do carvão}

No SÉCULO XIX, na Europa, quando o capitalismo industrial estava a pleno vapor, o jovem Friedrich Engels em seu livro A situação da classe trabalhadora na Inglaterra (1845) fez um estudo minucioso sobre vários aspectos das doenças dos trabalhadores, evidenciando os males que a indústria extrativa provocava aos operários desse setor:

Doença própria desses trabalhadores da extração do carvão é a expectoração negra (black spittle): provocada pela impregnação de poeira carbonífera nos pulmões, manifesta-se por fraqueza geral, dores de cabeça, dificuldade respiratória e expectoração de catarro negro. ${ }^{1}$

1 ENGELS, Friedrich. A situação da classe trabalhadora na Inglaterra. São Paulo: Editora Boitempo, 2008. p. 280. 
As doenças respiratórias eram as que mais acometiam os mineiros. Vivendo boa parte de suas vidas no subterrâneo, em abafadas galerias, o trabalho de extração de carvão demandou sempre grandes levas de trabalhadores para manter o ritmo de produção e repor a mão de obra perdida em virtude de acidentes e mortes. Na França, Émile Zola deu vida literária ao narrar o encontro do jovem Etiene na mina de carvão Voreux, com um velho carroceiro, "Boa Morte", que recebera esse nome devido ter escapado de inúmeros acidentes dentro da mina. Etiene, com aparência de 21 anos, aspecto vigoroso, quando de sua chegada pergunta se aquilo era uma mina e se tinha emprego para operador de máquinas. Em seguida, o velho "Boa Morte" responde que: "Trabalho para operador de máquinas, não, não há. Ainda ontem apareceram dois, mas não há nada". ${ }^{2}$ O jovem lança mais uma pergunta ao velho, mas "desta vez o velho não pôde responder, um violento acesso de tosse o sufocava. Por fim, escarrou, e seu escarro fez uma mancha negra no chão avermelhado". ${ }^{3}$

O tom naturalista pintado por Zola denunciou a precariedade do trabalho mineiro, tornando-o conhecido no mundo. Impressiona um pouco o detalhamento a respeito das condições de saúde dos trabalhadores, até mesmo do ponto de vista clínico para aquela época e as semelhanças narradas sobre a mineração na Inglaterra e na França com o que aconteceu no sul do Brasil, embora em contextos históricos bem diferentes, em que a expectoração do "catarro negro" fazia-se presente também no cotidiano dos trabalhadores que adquiriam doenças pulmonares. Sobre o desgaste físico que provocava o envelhecimento precoce, as semelhanças também são notórias: Engels observa que em geral, entre os 35 e 45 anos de idade, os homens estão ineptos para o trabalho. ${ }^{4}$ Não por acaso que foram nesses dois países narrados por Engels e Zola, Inglaterra e França, que explodiu o "levante gêmeo" como se refere Hobsbawm à Revolução Industrial e à Revolução Francesa, "que se deu naqueles dois países e que dali se propagou por todo o mundo". ${ }^{5}$

Foram nesses países, entre final do século XVIII e começo do XIX, que o que se conhece hoje por Saúde Pública começou a ser debatida e implementada com o objetivo de sanar as debilidades da explosão urbana e demográfica fruto do processo de industrialização acelerada e do êxodo rural. A insalubridade das cidades, caracterizadas por habitações anti-higiênicas em que viviam um grande número de pessoas num mesmo cômodo, a falta de esgoto e de água potável, a concentração de lixo nas ruas disseminavam doenças infectocontagiosas que matavam ricos e pobres. Em meados do século XIX, o problema não havia sido solucionado, segundo Hobsbawm: "apesar da reforma sanitária e do pequeno planejamento que ali havia, o problema da superpopulação talvez tenha crescido nesse período sem que a saúde ou a taxa de mortalidade tenham melhorado, se é que não pioraram de fato". ${ }^{6}$

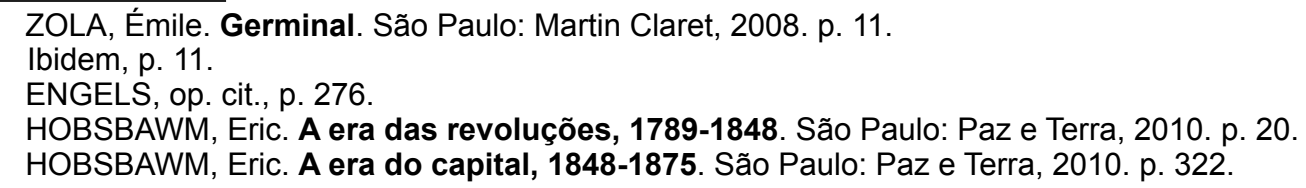


No Brasil, a saúde pública como política de Estado surgiu em meados do século XIX, quando foi criada a Junta Central de Higiene Pública, em 1850, encarregada de zelar pelas questões de saúde pública. ${ }^{7} \mathrm{O}$ ideal de construção de uma nação "civilizada" impregnou o pensamento de médicos e engenheiros voltados para o controle de epidemias e para a formação ética e moral de um tipo ideal de brasileiro. ${ }^{8}$ Chalhoub, quando discute o surgimento da "ideologia da higiene" no Brasil, demonstra que as elites do Rio de Janeiro viam as classes pobres como "perigosas" não só porque poderiam interpelar a ordem pública, mas porque ofereciam o "perigo de contágio". ${ }^{9}$ Desse modo, preconizava-se por um lado a prevenção das moléstias através da intervenção nos lares e o saneamento de lugares públicos, além de fomentar hábitos de higiene na população; ${ }^{10}$ e por outro lado, a imigração em massa de europeus com o objetivo de fomentar o "branqueamento" da população.

Se o viés higienista avançou na saúde pública no começo do século XX, ela se mostrava insuficiente para dar respostas ao rápido aumento de doenças e acidentes que acometiam uma grande parcela da população: a classe trabalhadora. Foi somente na primeira metade do século $X X$, com o crescimento das indústrias nas cidades, que a medicina do trabalho se desenvolveu de modo abrangente: ao revés das discussões sobre a higiene social e debates sanitaristas, a medicina do trabalho se voltava a prevenir e diagnosticar o surgimento de doenças que afetavam principalmente os trabalhadores. ${ }^{11}$

Em meio a esse processo, os médicos do trabalho se dedicavam à constituição desse novo saber, que incluía pesquisas sobre as relações entre as condições de trabalho e saúde, e de que modo as doenças profissionais afetavam os trabalhadores. Isso incluía, segundo Anna Beatriz de Sá Almeida, discussões que buscavam definir o que era considerado uma "moléstia do trabalho, uma doença do trabalho, uma moléstia profissional, uma doença profissional atípica (...), definições estas que foram sendo definidas ao longo do processo de constituição desse campo". ${ }^{12}$ Foi nesse contexto que a entrada em cena do operariado

7 CHALHOUB, Sidney. Cidade febril: cortiços e epidemias na Corte Imperial. São Paulo: Companhia das Letras, 1996. p. 30.

8 CAROLA, Carlos R. Assistência médica, saúde pública e o processo modernizador da região carbonífera de Santa Catarina (1930-1964). 2004. Tese (Doutorado) - Faculdade de Filosofia, Letras e Ciências Humanas, Universidade de São Paulo, São Paulo, 2004. p. 22.

9 CHALHOUB, op. cit., p. 29.

10 É importante lembrar que desde 1904 ocorreu no Rio de Janeiro uma revolta popular contra medidas sanitaristas que tentavam obrigar o povo à vacinação obrigatória contra a varíola, operação liderada pelo médico sanitarista Oswaldo Cruz. Para o historiador Nicolau Sevcenko (2018, p. 8), os argumentos do governo para obrigar a vacinação "era de que a vacinação era de inegável e imprescindível interesse para a saúde pública". Segundo Chalhoub (1996, p. 97), diante do anúncio de que a vacina seria obrigatória, milhares de pessoas saíram às ruas "e enfrentaram as forças da polícia, do exército, e até do corpo de bombeiros e da marinha". As manifestações que envolveram parte considerável da população pobre da capital do país, que ficou conhecida como Revolta da Vacina, era resultado da tentativa do governo de impor uma prática médica "moderna" às populações que possuíam distintos costumes, aprendizados e histórias no que dizia respeito ao cuidado com a saúde e com o corpo. A revolta provocou uma grande manifestação popular, com quebra de meios de transporte e ataque a agentes higienistas, além de um saldo de cerca de 30 mortos e 110 feridos no confronto com a polícia. Cf.: SEVCENKO, Nicolau. A Revolta da Vacina. São Paulo: Unesp, 2018.

11 DUARTE, Adriano Luiz; GALLO, Óscar. Trabalho, saúde e medicina na América Latina. Mundos do Trabalho, Florianópolis, v. 7, n. 13, p. 5-8, mar. 2016, p. 5.

12 ALMEIDA, Anna Beatriz de Sá. Doenças e Trabalho: um olhar sobre a construção da especialidade Medicina do Trabalho. In: NASCIMENTO, Dilene Raimundo do; CARVALHO, Diana Maul de; MARQUES, Rita de Cássia (org.). Uma história brasileira das doenças. Rio de Janeiro: Mauad, 2006. p. 181. 
da grande indústria moderna e as consequentes doenças e acidentes produzidos em larga escala levou ao crescimento da medicina do trabalho, tal como refletiram Duarte e Gallo:

(...) um dos pilares da medicina do trabalho, da discussão sobre acidentes do trabalho e doenças profissionais, foi um grupo de sujeitos diferenciados pelos direitos sociais, concretamente, pelo direito de receber indenizações por acidentes e danos fisiológicos e psíquicos produzidos pelo trabalho. ${ }^{13}$

Portanto, a ideia de doença como um fato social e não como algo natural, fruto das condições de trabalho e não somente de características herdadas biologicamente, fez com que emergisse na medicina uma área especializada na prevenção dessas doenças e acidentes, para que fossem evitadas, ou ao menos minimizadas. O surgimento desse campo de estudo e prática médica que iniciou no século $X X$, espalhou-se rapidamente por vários países, concomitantemente com as manifestações e greves operárias por melhores condições de trabalho e de salário. $O$ fato do perigo que representava a miséria dos trabalhadores, ao final da Primeira Guerra Mundial, favorecia movimentos proletários que se mexiam e reivindicavam condições mais dignas de trabalho. Após o fim da Primeira Guerra em 1919, com a assinatura do Tratado de Versalhes, no qual o Brasil foi signatário, efetivou-se a criação da Organização Internacional do Trabalho (OIT), que entre outras medidas recomendava o reconhecimento dos novos direitos sociais como a já mencionada redução da jornada de trabalho para oito horas diárias e máximo 48 semanais. A constituição da OIT, em seu preâmbulo, já afirmava que:

Considerando que existem condições de trabalho que implicam, para grande número de indivíduos, em miséria e privações, e que o descontentamento que daí decorre põe em perigo a paz e a harmonia universais, e considerando que é urgente melhorar essas condições $(\ldots.) .^{14}$

É importante observar, portanto, que aquele era um contexto de criação e expansão de direitos sociais em nível internacional. Em França, que durante décadas possuiu uma economia com forte base na extração do carvão mineral, chegando a uma produção de 59 milhões de toneladas em $1930,{ }^{15}$ a questão médica se fazia presente nas reivindicações operárias. As greves e paralisações mineiras incluiam em suas reivindicações a melhoria das condições de trabalho, a redução da jornada para oito horas diárias (conquistada em 1919) - o que implicava em maior tempo de descanso -, a segurança nas minas e o aumento salarial.

Essa preocupação com a segurança do trabalho cresceu nos anos pós-Segunda Guerra Mundial, quando todas as indústrias do país foram nacionalizadas em 1946. No site do Archives nationales du monde du travail, em que consta a exposição Mines et mineurs de

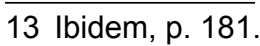

14 MUNAKATA, Kazumi. A legislação trabalhista no Brasil. São Paulo: Editora Brasiliense, 1981. p. 31.

15 "Até a Primeira Guerra Mundial, a produção é errática. Aumenta consideravelmente entre 1850 e 1900 , passando de 4,3 milhões de toneladas para quase 40 milhões! Em 1930, atingiu um máximo de 59 milhões de toneladas, renovada apenas em 1959". Exposição virtual: Mines et mineurs de charbon entre réalité et imaginaire: Les rendements. Disponível em: http://www.archivesnationales.culture.gouv.fr/camt/fr/memoires/ donnees_expositions/06_11_06-07_07_27_mines/expo_virtuelle/html/exploitation_charbon/rendements.php. Acesso em: 30 jan. 2019. Trädução do autor. 
charbon entre réalité et imaginaire, existe uma seção sobre as condições de trabalho com fotos dos mineiros no trabalho, entre as quais reproduziremos duas fotografias da coleção:

Fotografias 1 e 2 - Mineiros franceses perfurando as frentes de trabalho. Houillères da bacia Nord-Pas-de-Calais, Grupos Henin-Liétard e Henri Leland: fotografia, 1950.
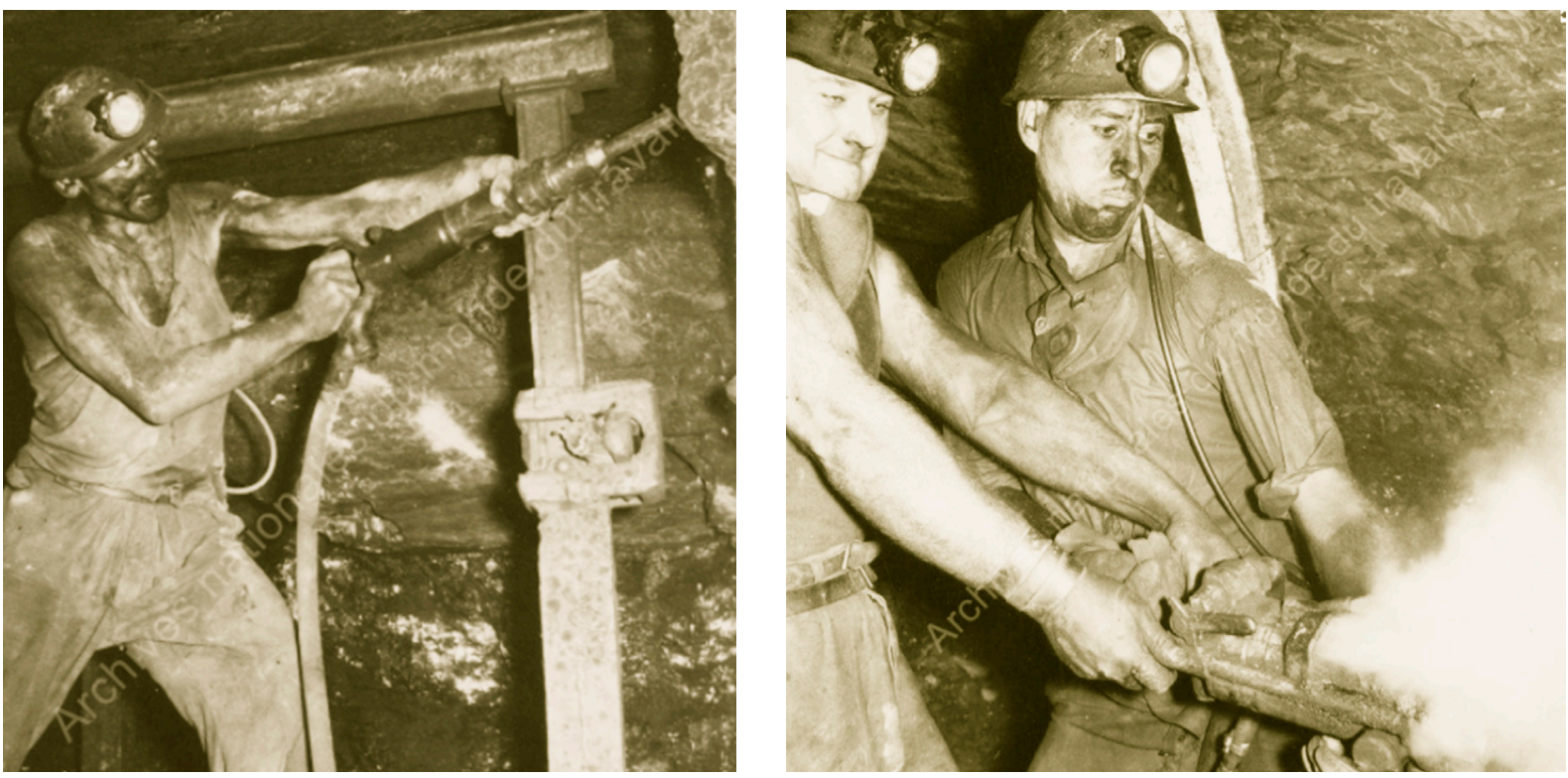

Fonte: ANMT, Fundo HBNPC, 2005, 039. ${ }^{16}$

Nas imagens acima, do ano de 1950, é possível identificar algumas situações: em ambas se verificou que os trabalhadores executam a perfuração das frentes de carvão com o uso de máquinas chamadas de marteletes, perfuratrizes ou furadeiras automáticas. A utilização dessas máquinas para perfurar as paredes das galerias produz vibrações no corpo dos trabalhadores, o que poderia provocar diversas alterações no organismo humano. ${ }^{17}$ Além disso, em ambas imagens os mineiros estão sem máscaras, o que provocava absorção pela inalação da poeira e partículas liberadas pela atividade de perfuração, o que causava a antracose, popularmente conhecida por pneumoconiose.

Em França, essa doença foi chamada de "la grand enfermedad del trabajo em el siglo XX" ${ }^{18}$ Em outros países, como na Espanha, Navarro estudou a incidência dessa doença pulmonar nos mineiros, concluindo também ser a maior causadora de mortes no trabalho nesse século, apesar do esquecimento nos últimos anos. Segundo o autor:

(...) Embora a pneumoconiose pareça ter desaparecido da memória coletiva como uma ameaça à saúde dos trabalhadores em muitos países, a patologia

16 Exposição virtual: Mines et mineurs de charbon entre réalité et imaginaire: Les conditions de travail. Disponível em: http://www.archivesnationales.culture.gouv.fr/camt/fr/memoires/donnees_expositions/06_11_06-07_07 27 mines/expo virtuelle/html/peuple nuit/travail.php. Acesso em: 30 jan. 2019.

17 FUNDACENTRO, 1985 apud VOLPATO, Terezinha Gascho. Vidas marcadas: trabalhadores do carvão. Tubarão: Unisul, 2001. p. 46.

18 ROSENTAL, Paul André; DEVINCK, Jean Claude. Estadística y muerte industrial: la fabricación del número de víctimas de la silicosis em las minas de carbón em Francia, de 1946 hasta nuestros días. In: GALLO, Óscar; CASTAÑO, Eugenio (org.). La salud laboral el siglo XX y el XXI - De la negación al derecho a la salud y la enfermidade. Colômbia: Escuela Nacional Sindical, 2016. p. 143. 
respiratória derivada da inalação de diferentes substâncias pulvigênicas tem sido a principal causa de morte no trabalho durante o século $X X .{ }^{19}$

Segundo dados do mesmo autor, essa patologia foi responsável pela morte de 1.200 trabalhadores por ano na Inglaterra e Galles, com 4.500 novos casos diagnosticados todo ano na Grã-Bretanha. Em França, apesar dos dados oficiais serem subestimados, as estatísticas registraram entre 800 e 1.000 falecimentos anuais dos mineiros que trabalharam na extração do carvão pela "silicose" entre 1955 e 1985. ${ }^{20}$

Se na Europa a exploração do carvão mineral produziu milhares de vítimas acidentadas e doentes, não foi diferente no continente latino-americano. Devido ao crescimento populacional, à vertiginosa explosão demográfica e à industrialização tardia dos países latino-americanos, muitos problemas sociais gerados na Europa no século XVIII e XIX foram experimentados em nosso continente somente no século XX. Na realidade, uma discussão médica em âmbito internacional destacava os efeitos nocivos que o trabalho industrial produzia, em especial a questão da fadiga industrial, que produzia uma série de doenças profissionais e acidentes de trabalho, que produziam impactos tanto no rendimento do trabalho quanto nos custos sociais desses acidentes.

Óscar Gallo, que estudou a questão da medicina do trabalho na Colômbia, salientou que na primeira metade do século $\mathrm{XX}$ o país estava passando por mudanças sociais frutos da industrialização, e que isso se refletiu no âmbito das discussões médicas sobre como prevenir os efeitos da fadiga industrial. $O$ autor relata em seu livro que os médicos colombianos passaram a identificar nas doenças profissionais e acidentes de trabalho uma grande relação com as péssimas condições de vida e de salários, que eram extremamente baixos para atender as suas necessidades e de suas famílias, como observou o médico Miguel María Calle, médico da empresa mineira El Zancudo, do ramo do carvão mineral, uma das maiores da Colômbia até a primeira metade do século XX:

Calle observou a relação entre trabalho e as terríveis condições em que os trabalhadores viviam devido aos últimos eventos políticos e econômicos que ocorreram na Colômbia na primeira metade do século XX. (...) Para Calle, era um problema de pobreza. Os salários eram absurdamente insuficientes para atender às demandas de uma família de cinco a seis pessoas. (...) Afirmou que os filhos dos trabalhadores estavam sujeitos a influências perniciosas, o que os tornava candidatos perfeitos à degeneração astênica. (...) Somavam-se a isso casas estreitas, pouco ventiladas e úmidas, sem água potável, roupas insuficientes e inadequadas. ${ }^{21}$

Gallo comenta que questões como essas foram lançadas também pelo médico Emilio Morales (1937), que se questionava se o problema da alimentação da classe operária teria uma

19 NAVARRO, Alfredo Menéndez. De líneas rectas y renglones torcidos: el reconocimiento de la neumoconiosis de los mineros del carbón em Espanã (1930-1944). In: GALLO, Óscar; CASTAÑO, Eugenio (org.), op. cit., p. 31. Tradução do autor.

20 Ibidem, p. 32

21 GALLO, Óscar. Luz sobre el fenómeno de un corazón aparentemente infatigable: La fatiga de la clase obrera em Colombia, 1898-1946. In: GALLO, Óscar; CASTAÑO, Eugenio (org.), op. cit., p. 221. Tradução do autor. 
estreita relação com o salário mínimo, que deveria dar ao trabalhador o poder de comprar os alimentos necessários de acordo com o esforço que o trabalho exigia. ${ }^{22} \mathrm{O}$ médico também se perguntava se a menor resistência orgânica e as enfermidades infecciosas não eram resultado da má alimentação dos trabalhadores que estavam expostos permanentemente à fadiga. ${ }^{23}$

É evidente que esses debates sobre a fadiga da classe trabalhadora não eram fruto somente das preocupações sociais dos médicos em melhorar as condições de vida dos operários, mas também uma necessidade das indústrias em encontrar respostas para minimizar as perdas da produção resultantes da fadiga industrial e dos acidentes. Ainda de acordo com Gallo, esse horizonte de questões lançadas pelo debate médico dizia respeito à noção de "fator humano", uma corrente de pensamento da medicina do trabalho que abarcava uma série de medidas que deveriam ser evitadas a fim de reduzir os acidentes na indústria: a falta de seleção profissional, a falta de prevenção ou racionalização de tarefas e as deficiências anatômicas. ${ }^{24}$

Essa emergente discussão travada na Colômbia, na primeira metade do século XX, era parte de um movimento global que se preocupava com os possíveis impactos econômicos e sociais das doenças produzidas pelo trabalho. As condições de trabalho e de vida encontrada pelo médico Miguel María Calle, assim como as informadas pela exposição das minas de carvão em França, não diferiam muito das condições sociais dos mineiros do sul do Brasil em meados do século $X X$, conforme veremos a seguir.

\section{Acidentes de trabalho e doenças profissionais na mineração de carvão no sul do Brasil}

No sUL Do BRASIL, em meados do século XX, o regime de trabalho nas minas era de intensa exploração, com jornadas de trabalho de oito horas por dia mas que podiam chegar até 16 horas no subsolo (devido ao "doble", a dupla jornada). ${ }^{25}$ Tanto em Criciúma (Santa Catarina) quanto em São Jerônimo (Rio Grande do Sul), a maioria das minas era de "poço", ou seja, uma abertura escavada até o subsolo sendo o transporte feito através de elevadores, as "gaiolas", na linguagem dos mineiros.

O mineiro Jorge Feliciano, que trabalhou na C.B.C.A em Criciúma como ajudante de mineiro e depois como mineiro, relembra como era a descida até o subterrâneo: "Lotada com 12 mineiros, a gaiola cai vertiginosamente em direção ao fundo do poço (...). Lá embaixo, os grupos espalhavam-se pelas galerias, como num formigueiro. Trabalhavam quase sem

\footnotetext{
22 Ibidem, p. 227.

23 Idem, p. 227

24 Ibidem, p. 238.

25 SPERANZA, Clarice G. Cavando direitos: as leis trabalhistas e os conflitos entre trabalhadores e patrões nas minas do Rio Grande do Sul nos anos 40 e 50. 2012. Tese (Doutorado em História) - Programa de Pós-Graduação em História, Universidade Federal do Rio Grande do Sul, 2012. p. 59.
} 
ventilação" ${ }^{26}$ Sua descrição minuciosa impressiona pela precariedade em que era exercido o trabalho:

O ar era tão viciado que não tinha oxigênio suficiente para que se riscasse um fósforo, o calor era tão intenso que os mineiros trabalhavam nus ou seminus, as galerias tão estreitas que eles eram forçados a manejar as picaretas deitados ou encurvados, o que Ihes traria sérios problemas de coluna no futuro. Os mineiros trabalhavam sem proteção de botas ou capacetes, das quatro, cinco horas da manhã, às quatro, cinco horas da tarde. ${ }^{27}$

Essa descrição das condições de trabalho é muito comum no relato dos aposentados. Orfelino Teixeira Machado "Cortador", natural de Encruzilhada do Sul, trabalhou de 1947 a 1952 na Mina do Recreio pelo Departamento Autônomo de Produção Mineral (DACM); posteriormente, de 1952 a 1958, nas Minas de Butiá. Lembra que "perdeu muito de sua saúde, que a aposentadoria é baixa, que só trabalhou à noite, que havia pouca ventilação nas galerias, com os fios desencapados, muita água, lodo, ratos mortos e fezes humanas". 28

Importante que se diga que a denominação "mineiros" engloba uma gama de funções desempenhadas por trabalhadores dentro das minas, relacionadas às etapas de extração do carvão mineral. As diferentes etapas de produção fazem parte de uma engrenagem movida pelos trabalhadores com a execução de processos sucessivos que se inicia com a abertura da galeria, seguido pela extração do carvão, o seu transporte do subterrâneo até a saída do poço e o seu translado para a superfície, onde o minério era peneirado, lavado e transportado. Tanto em Criciúma como em São Jerônimo, as funções desempenhadas eram quase as mesmas, com mudança em relação aos nomes empregados em cada região. Por exemplo, os "tocadores de carros" em São Jerônimo eram chamados de "vagoneteiros" em Criciúma, trabalhadores responsáveis por transportar os carros até a superfície nas minas manuais. $O$ escorador (ou madeireiro no RS) era o mineiro responsável pelo escoramento do teto, feito àquela época com toras de eucalipto, sendo uma profissão de grande risco, pois "o mineiro furador de teto está exercendo seu trabalho sob um teto não escorado". ${ }^{29} \mathrm{Na}$ próxima página, na fotografia 3 , da década de 1950, um acidente ocasionou a morte de um mineiro devido ao desabamento de uma pedra.

Além do escorador de teto, um trabalho de grande risco é exercido pelos furadores e pelos queimadores: enquanto aqueles são responsáveis pelo corte da rocha e pela extração do minério, os queimadores (ou "cartucheiros" no RS) são responsáveis pela queima com explosivos. Segundo Volpato, a vulnerabilidade desses trabalhadores tem consequências graves para o corpo do trabalhador: "os acidentes resultantes das práticas de trabalho com explosivos são frequentes, de marcas profundas, provocando mutilação grave e, em geral, a morte". ${ }^{30}$

26 COIMBRA, David. Atravessando a escuridão: memórias de um comunista casual. Criciúma: Editora Unesc, 1996. p. 20-21.

27 Idem, p. 20-21.

28 VEIT, Benedito. Mineiros, uma raça. São Jerônimo: Ed. do autor, 1993. p. 48.

29 VOLPATO, op. cit., p. 43.

30 Ibidem, p. 47. 
Fotografia 3 - Mineiro morto após o desabamento de uma pedra no interior da galeria. Mina de carvão em Criciúma, década de 1950.

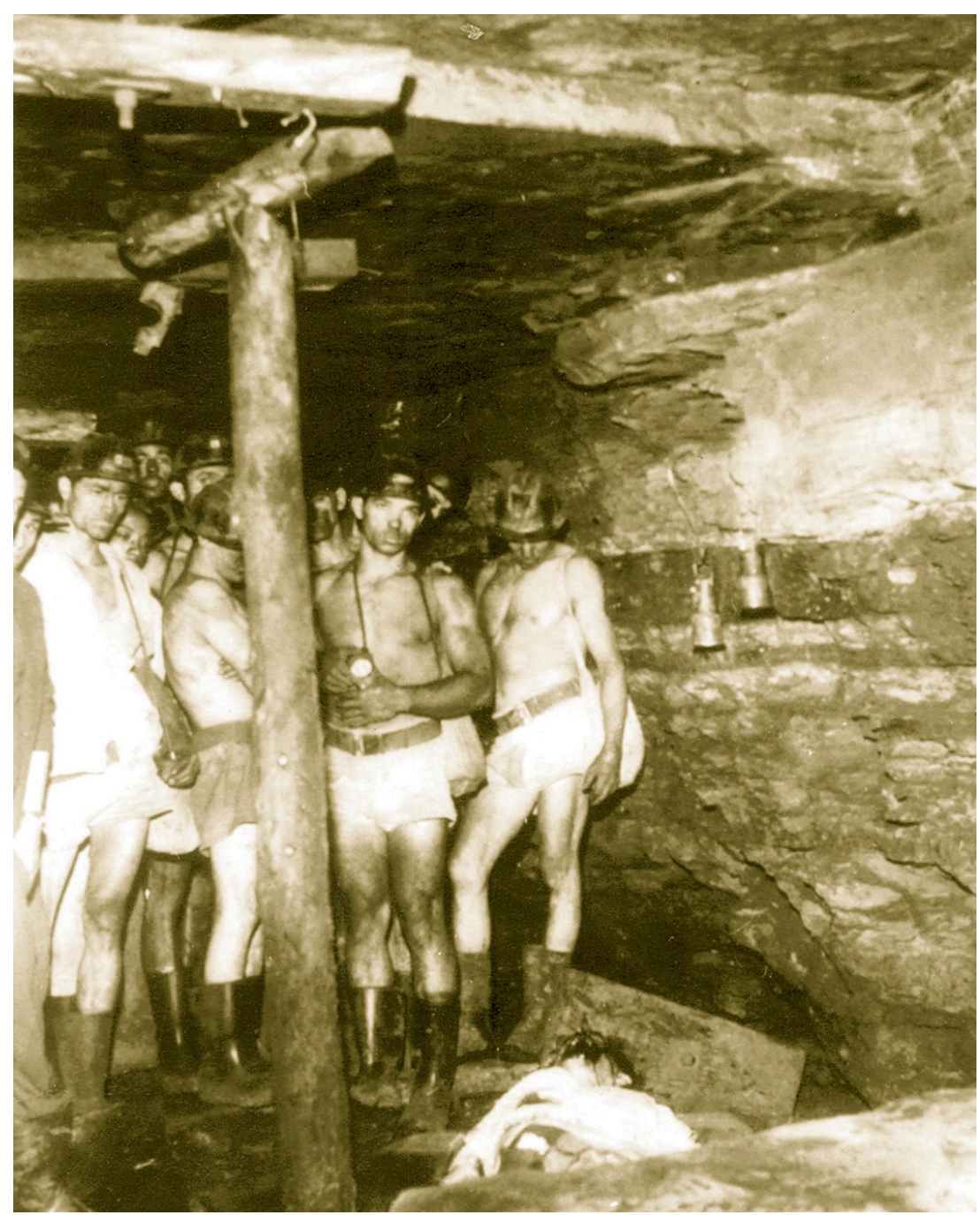

Fonte: Acervo de imagens do Cedoc/Unesc.

Em Santa Catarina identificamos duas percepções distintas dos médicos sobre o campo da medicina do trabalho e sua aplicação prática nos casos dos mineiros acidentados. Através de fontes autobiográficas deixadas pelo médico paranaense Manif Zacharias, que viveu e trabalhou entre 1944 e 1964 em Criciúma, pode-se ter uma visão da medicina mais próxima do social. O jovem médico, naquele tempo com 25 anos, havia chegado à cidade em $1^{\circ}$ de maio de 1944 para trabalhar, "tudo esperando de um futuro promissor". Em seu livro autobiográfico, Minha Criciúma de ontem, Manif se refere à cidade em que "tudo Ihe minguava, a começar pelo saneamento básico. Não possuía água canalizada, nem rede de esgotos". ${ }^{31}$

De fato, pôde-se perceber que Manif era quem mais se aproximava das demandas da classe trabalhadora, muito provavelmente por ter sido, desde o começo, encarregado de atender os casos de acidentados e emergências nas minas de carvão do sul do estado e 
ter sido membro do Partido Comunista Brasileiro (PCB). Sobre sua atuação política, o autor comenta em seu livro quando fala sobre seu companheiro de partido Lacombe Filho:

Comunista convicto, conhecedor profundo de Marx, Engels e Lenine, organizou e dirigiu, durante o período da legalidade, o secretariado municipal do P.C.B, de que fui, durante algum tempo, integrante. Juntos, participamos de muitas lutas políticas, enfrentando, em todas elas, a reação brutal de um reacionarismo de direita intolerante e perverso. ${ }^{32}$

Em virtude de seu trabalho, que vivia em contato diário com os mineiros, o médico desenvolveu um senso de solidariedade para com aqueles trabalhadores que viviam uma vida difícil, tal como relata em seu livro:

Era com essa classe operária, com esses mineiros, que mais me afinava, sentindo no íntimo as agruras, as privações por que passavam, vítimas inermes que eram de um iníquo regime econômico, explorados por nefandos contratos de trabalho que os matavam aos poucos, que os matavam literalmente (...). A Criciúma que vivi foi a desses mineiros, soterrados ou esmagados sob o peso de galerias desabadas, mineiros que eu, em ocasiões inúmeras, ajudei a retirar lá de baixo, sob toneladas de pedras, em meio ao lodo sanguinolento e pegajoso; a Criciúma das galerias inundadas, os trilhos de madeira gastos e desconjuntados, a exigirem redobrado e exaustivo esforço dos vagoneteiros ladeira acima; dos mineiros sem máscara de proteção, a antracose devastando inapelavelmente seus pulmões, talando cedo suas vidas ou invalidando-os para sempre aos 35 ou 40 anos de idade. ${ }^{33}$

A narrativa do médico, embora a tenha escrito quase 50 anos após sua vivência e experiência, demonstra sua preocupação com a péssima condição de vida e de trabalho dos mineiros, que deteriorava sua saúde e os matava "literalmente". Na fotografia abaixo, o médico Zacharias examina um mineiro que foi morto com o desabamento de pedras de uma mina.

\section{Fotografia 4 - Dr. Manif realizando exame cadavérico de mineiro vitimado em desabamento de galeria.}

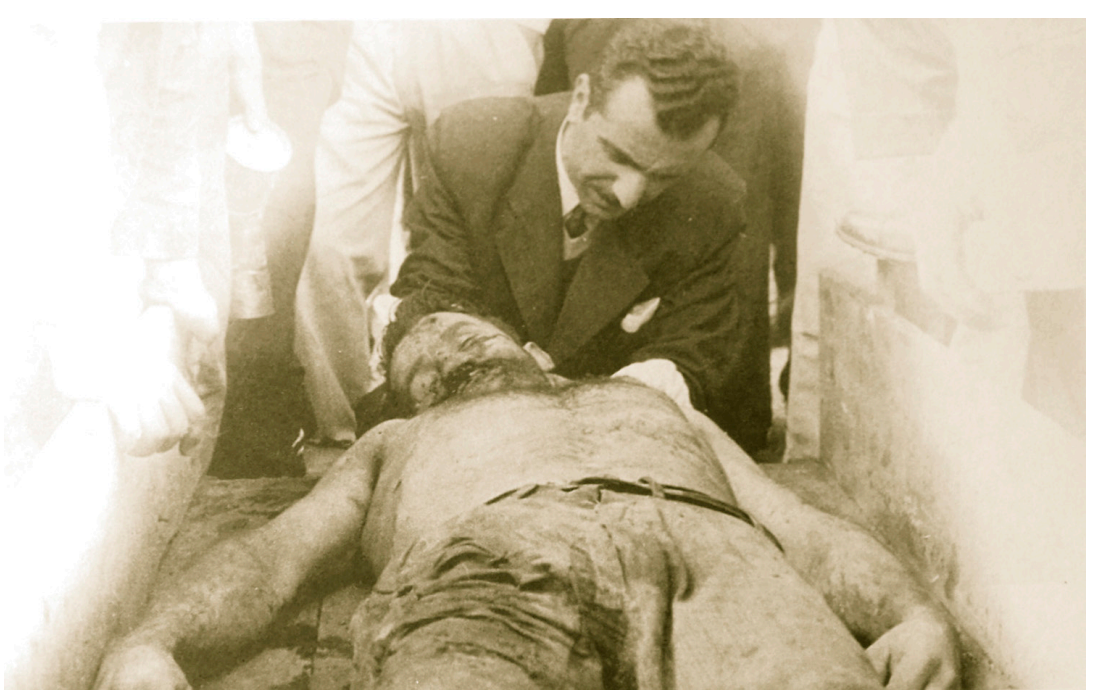

Fonte: ZACHARIAS, op. cit., 1999.

32 ZACHARIAS, Manif. Minha Criciúma de ontem. [S. I.]: Ed. do autor, 1999. p. 68, grifos nossos. 33 Ibidem, p. 20, grifos nossos. 
Além da autobiografia, foi possível perceber também, nos processos de acidentes de trabalho pesquisados, que o médico agia em defesa dos trabalhadores acidentados e doentes, para garantir-lhes ao menos uma indenização referente à incapacidade temporária ou permanente sofrida. Não agia à revelia da lei. Contudo, como o direito é um terreno de conflito entre partes desiguais, em que muitas vezes o costume prevalece sobre a norma ou como diria Thompson, "uma arena na qual interesses opostos apresentavam reivindicações conflitantes", ${ }^{34}$ foi possível observar uma atuação médica voltada para as reivindicações da classe trabalhadora, em prol de seus direitos.

Assim, em numerosos casos que eram encaminhados a Manif Zacharias como perito médico responsável, uma grande quantidade era considerada procedente de acidente ou moléstia profissional passível de indenização. É possível supor que o fato de sua atividade profissional ter requerido intensa ligação com os trabalhadores do subsolo, fez com que sua experiência vivida alterasse o modo como sentia e agia em relação à classe trabalhadora mineira. Talvez por conta dessa sua atuação muito ligada às demandas da classe trabalhadora que o médico tenha se filiado ao PCB e sido preso com o golpe de 1964.

Uma visão um pouco distinta sobre a medicina do trabalho foi de Francisco de Paula Boa Nova Jr., médico sanitarista do Departamento Nacional de Produção Mineral, formado na Faculdade de Medicina do Rio de Janeiro. Boa Nova Jr. chegou no mesmo ano de Manif Zacharias e permaneceu até 1952, período no qual se dedicou a coletar informações sobre as condições de vida dos trabalhadores da mineração. O resultado de suas expedições deu-se com a publicação do relatório denominado Problemas médicos e sociais da indústria carbonífera sul-catarinense, resultado de oito anos de experiência como médico na região, em que registrou suas impressões dessa cidade e do trabalho na mineração.

O médico sanitarista estava inserido no debate da medicina do trabalho que repercutia no Brasil e na América Latina em meados do século XX. De maneira geral, essa medicina estava preocupada com os efeitos nocivos da indústria moderna, principalmente no debate sobre a fadiga industrial, que apontava como solução a organização do trabalho e a prevenção dos acidentes através de uma racionalização das técnicas de trabalho e uma melhor seleção dos operários, a fim de prevenir os acidentes.

O autor comenta essa questão em seu relatório quando trata da Fadiga na indústria carbonífera. Diz o autor que a fadiga industrial, além de fatores individuais, é fruto da existência de outros fatores: os fatores que dependem das condições de trabalho e outros, "estranhos ao trabalho", como as ocupações suplementares, a alimentação inadequada ou insuficiente, os "desregramentos da vida", o abuso do álcool, as habitações anti-higiênicas, entre outras. ${ }^{35}$

34 THOMPSON, Edward P. Costumes em comum: estudos sobre a cultura popular tradicional. São Paulo: Companhia das Letras, 2015. p. 17.

35 BOA NOVA JR., Francisco de Paula. Problemas médico-sociais da indústria carbonífera catarinense. Rio de Janeiro: Departamento de Fomento da Produção Mineral, 1953. p. 65. 
Além disso, Boa Nova Jr. comenta a importância de regulamentar o trabalho pesado que exigia grande esforço físico do operário, e limitar "para cada operário ou operária, peso e volume compatíveis com sua capacidade física, regularizar-se o trabalho e estabelecer pausas necessárias". ${ }^{36}$

O autor do estudo reconhece que uma das principais causas dos acidentes era a fadiga dos trabalhadores que, não recebendo suficientemente pelo serviço que exerciam, e "em virtude de perceberem salários baixos em relação ao atual custo de vida", exercem ocupações suplementares em outras atividades após o trabalho na mina. Em muitos casos, havia operários que duplicavam sua jornada de trabalho nas minas, "trabalhando exaustivamente, num serviço por si só já penoso em um só turno, por dois turnos consecutivos, de seis horas cada". ${ }^{37}$

Essa situação de dupla jornada de trabalho nas minas de Criciúma já vimos quando do acidente do operário Luiz Francisco de Mello. A notoriedade dada pelo médico confirma que era realmente muito comum a duplicação da jornada de trabalho na década de 1940. Outro fator fundamental da fadiga industrial para o médico era a má alimentação da família operária, da qual trata em seu relatório em um capítulo específico, dada a importância do assunto.

Existia uma estreita relação com o tema da fadiga industrial com o debate sobre o fator humano, isto é: a ideia do acidente de trabalho como resultado do fator humano exercia forte influência no pensamento médico durante o período pesquisado. De acordo com Gallo, a ideia de fator humano surgiu em resposta ao mecanicismo taylorista, pois partia da problematização do homem como pura força ou motor humano. ${ }^{38}$ Para autores desse campo médico, além de atenuar a clássica visão do motor humano, estavam mais focados na preocupação com o rendimento, na diminuição do preço e aumento do volume da produção, desafios fundamentais na racionalização científica do trabalho. ${ }^{39}$ Sobre esse aspecto podemos verificar na obra do médico Boa Nova Jr. preocupações muito próximas à teoria do fator humano.

Uma vez que, em sua opinião, a prevenção do acidente de trabalho passava, entre outras causas, pela melhor seleção e exame médico dos operários a serem admitidos pelas companhias mineradoras, bem como um exame periódico a fim de garantir a qualificação da mão de obra. ${ }^{40}$ Com esses métodos de admissão e de avaliação, o médico acreditava na prevenção dos acidentes, tal como escreve:

A prática dos exames prévios à admissão para todos os operários é hoje medida preconizada universalmente pelas autoridades em higiene do trabalho, sendo imperdoável que se empregue, ainda hoje, para trabalhos no subsolo, como ocorre em Criciúma, operários que não passam pelo crivo de um exame médico rigoroso, subnutridos e de físico franzino, muitos deles já portadores de doenças crônicas, cuja sintomatologia, às vezes berrante, ressalta a uma simples inspeção do facies do candidato, como é o caso

\footnotetext{
36 Ibidem, p. 64.

37 Ibidem, p. 64.

38 GALLO, op. cit., p. 243.

39 Ibidem, p. 244.

40 BOA NOVA JR., op. cit., p. 50.
} 
da ancilostomíase e o da doença de Chagas, para só citarmos duas das entidades mórbidas frequentes no nosso (...). Se o operário pouco eficiente é o que mais está sujeito a acidentes de trabalho e se o baixo rendimento decorre muitas vezes da enfermidade, a pesquisa desta se impõe e é medida profilática de grande valia. Afastando-se do serviço o operário que não apresenta perfeitas condições de saúde, previne-se certamente o acidente de trabalho. ${ }^{41}$

Dessa maneira, uma das preocupações do médico do DNPM era de uma diminuição dos acidentes de trabalho, através da prevenção pelo exame prévio e periódico, para se descartar aquele operário que fosse pouco produtivo. O custo do acidente de trabalho também é tratado em sua obra. Racionalização, diminuição dos acidentes e custos, aumento da produtividade, são todas questões latentes em seu livro que fazem parte dessa corrente de pensamento adepta à teoria do fator humano.

Na sua visão, afastando-se os poucos produtivos e ineficientes do trabalho, evitava-se os acidentes, o que entra em contradição com algumas de suas ideias já expostas anteriormente quando elencou 11 causas fundamentais dos acidentes na mineração, dentre as quais somente cinco possuíam uma relação direta com o trabalho, ou com o "fator humano", teoria explicativa de Boa Nova Jr.

Entretanto, o médico lamenta que essa prática de seleção dos operários para ingresso seja feita sem o necessário "rigor", o que resultava em aposentados antes dos 40 anos de idade, com proventos irrisórios e "alquebrados e envelhecidos", sem condições de exercerem outras funções de trabalho por estarem "inutilizados".

Para além dessa linha de pensamento, existiam outras condições de trabalho citadas pelo médico também como causadores das doenças e acidentes, que são assim classificadas: os fatores químicos, os fatores biológicos e os fatores físicos. Em relação ao primeiro, o autor mencionou as poeiras, as fumaças, os gases e vapores que são dependentes do ambiente de trabalho, e que influenciam como causadores de doenças. ${ }^{42}$

As doenças de causas biológicas mencionadas são as infecções bacteriológicas que se originam da contaminação bacteriana do ar das minas e que eram muito frequentes, como por exemplo, a antracose, a tuberculose, a ancilostomíase, o nystagmus dos mineiros. ${ }^{43}$ Entre os fatores físicos que influenciam no desenvolvimento de doenças estão a umidade, o calor e o frio excessivo, a iluminação deficiente, entre outros causadores.

Sobre a antracose, também conhecida como pneumoconiose,${ }^{44}$ a doença dos pulmões causada pela aspiração do pó do carvão e das partículas químicas que se desprendiam das

41 Ibidem, p. 52, grifos nossos.

42 Ibidem, p. 91.

43 Ibidem, p. 90.

44 A pneumoconiose dos trabalhadores das minas de carvão é causada pela inalação de poeira de carvão. A deposição de poeira acarreta o aparecimento de macrófagos repletos de poeira em torno dos bronquíolos (máculas de carvão), causando, ocasionalmente, enfisema bronquiolar focal. LARA, Abigail R. Pneumoconiose dos carvoeiros. Disponível em: http://www.msdmanuals.com/pt/profissional/ dist\%C3\%Barbios-pulmonares/ doen\%C3\%A7as-pulmonares-ambientais/pneumoconiose-dos-trabalhadores-das-minas-de-carv\%C3\%A3o. Acesso em 15 jan. 2019. 
explosões, o médico Boa Nova Jr. discute o aparecimento de numerosos casos graves da doença entre os mineiros da região carbonífera de Santa Catarina.

Segundo o autor, o crescente diagnóstico entre a população mineira vai de encontro às teses médicas comuns à época de que "mesmo existindo impregnação dos pulmões em grau elevado, isto pode ocorrer sem qualquer sintomalogia séria"; segundo o autor, ainda, "à vista dos numerosos casos por nós observados entre o operariado das minas de carvão de Criciúma, a ponto mesmo de muitos deles, pela sintomalogia grave que apresentam, com dispneia intensa, dores torácicas acentuadas e tosse com expectoração difícil, terem sido aposentados (...)". 45

Atendendo os casos supracitados de deterioração do órgão pulmonar, o médico cita como um exemplo que investigou durante aquele período, um jovem de 24 anos de idade que trabalhava há seis anos de mineiro. Esse operário havia sido internado no hospital São José em Criciúma, acusando "fortes dores nas cadeiras". Contudo, dois dias após já se sentir mais aliviado das dores que se queixava, veio a falecer "repentinamente". Sobre a morte do mineiro, o autor afirmou que foi causada por um "colapso cardíaco consequente a uma degeneração gorda do coração (degenerescência alcóolica)". ${ }^{46}$ Todavia, a surpresa do médico ao relatar o momento da autópsia, levou-o às seguintes considerações:

Ao examinarmos os pulmões do cadáver, surpreendeu-nos a enorme quantidade de partículas de carvão neles acumuladas, melhor evidenciadas ainda pelos vários cortes efetuados nos pulmões retirados do cadáver: alvéolos, bronquíolos, brônquios finos e grossos, repletos de densas massas de carvão; e a faca, utilizada para os vários cortes praticados, nos dava a sensação de estar cortando um saco cheio de areia grossa. ${ }^{47}$

Desse modo, para o médico autor existia uma relação direta entre o trabalho nas minas de carvão e a doença antracose (pneumoconiose), fato que a evidenciava como doença profissional enquadrada na Lei de Acidentes de Trabalho, sob seu art. $2^{\circ}$, como doença profissional "inerentes ou peculiares a determinados ramos de atividades". 48

Dessa maneira, além dos frequentes acidentes da mineração (que geravam incapacidades permanentes, temporárias ou fatais), os trabalhadores também adquiriam doenças causadas pela aspiração do pó do carvão, pelas infecções pulmonares resultantes do ar contaminado do interior das galerias e das mudanças bruscas de temperaturas do interior das minas (que passava dos $40^{\circ} \mathrm{C}$ ) para a área terrestre (às vezes com temperaturas próximas a $\left.0^{\circ} \mathrm{C}\right)$.

Além disso, no interior das galerias formavam-se grandes "rios" de água que não eram corretamente esvaziadas e, em contato com a pirita, liberava elementos químicos ácidos

45 BOA NOVA JR., op. cit., p. 93.

46 Ibidem, p. 93.

47 Ibidem, p. 94.

48 BRASIL. Decreto-Lei n. ${ }^{\circ}$ 7.036, de 10 de novembro de 1944. Disponível em: http://www2.camara.leg.br/ legin/fed/declei/1940-1949/decreto-lei-7036-10-novembro-1944-389493-publicacaooriginal-1-pe.html. Acesso em: 19 jan. 2019. 
nocivos à saúde. Embora pareça que essa relação entre doença profissional - nesse caso a pneumoconiose - com o ambiente e as condições de trabalho como de causa e efeito, nem sempre foi assim, isto é, a constituição das doenças profissionais e o embate para que a lei as reconhecesse como tais, e indenizasse os trabalhadores pela incapacidade gerada, foi um processo de grandes embates ao longo dos anos, tanto no campo médico quanto no terreno jurídico. Anna Beatriz de Sá Almeida, que pesquisou sobre os casos de tuberculose na literatura médica, afirma que "cabia provar a relação de causalidade entre o trabalho e a doença, terreno bastante propício às mais diversas interpretações no qual tinham espaço as ações relativas a indenizações (...) de outras doenças não inerentes e peculiares ao trabalho". 49

$\mathrm{Na}$ área da medicina do trabalho e as doenças profissionais dos mineiros, por exemplo, muitos médicos ainda não reconheciam que o pó do carvão, assim como as partículas que este soltava através de gases e fumaças, fossem nocivas à saúde do trabalhador, a ponto de causar a pneumoconiose. Isso porque, até a década de 1950, com perfuratrizes e marteletes que geravam nuvens de poeira, as minas de carvão não adotavam o sistema mecanizado de extração, como se tornou comum a partir da década de 1960 e, principalmente, anos 1970. Carola comenta que "nessa época, a medicina do trabalho ainda não considerava a pneumoconiose uma doença grave". ${ }^{50}$ Desse modo, só posteriormente é que as pesquisas na área de medicina do trabalho evidenciaram as sérias consequências que a aspiração do pó do carvão, sem o uso de máscaras de proteção, causava à saúde dos trabalhadores.

Uma outra questão importante na área médica, em meados do século XX, era a disputa em torno da questão dos "verdadeiros" e dos "falsos" acidentes de trabalho. Essa discussão, associada à teoria do fator humano, apareceu no relatório do médico do DNPM, em um capítulo exclusivo para o que chama de "Maus Jeitos":

Dentre os chamados pequenos acidentes, tão frequentes nas minas de carvão de Criciúma, e que, pelo seu aumento crescente, estão já a exigir estudos acurados de suas causas, de sua prevenção, de um tratamento mais eficiente dos acidentados, de modo a abreviar-se a sua cura e, principalmente, ver os meios que permitam distinguir melhor os verdadeiros acidentados da grande massa de "simuladores de acidentes", citaremos o chamado "mau jeito", tão desmoralizado já como acidente nos meios médicos de Criciúma. Afirmamos sem receio de contestação que $70 \%$ ou $80 \%$ dos chamados "maus jeitos" verificados entre os operários das minas de carvão sul-catarinense são casos típicos de uma desavergonhada simulação. Tais casos, muito mal classificados como acidentes de trabalho, representam um ônus pesado para as companhias seguradoras e afetam de certo modo a economia das companhias carboníferas que, muito embora não sofram prejuízos imediatos, porquanto o acidentado passa para o seguro, ficando deste modo o seu tratamento sob a responsabilidade das

49 ALMEIDA, op. cit., 2006, p. 183.

50 CAROLA, Carlos R. Minas de carvão, enfermidades e estado civilizador: uma abordagem histórica sobre as doenças dos mineiros da região carbonífera de Santa Catarina. In: VIEIRA, R. S.; CUSTÓDIO, A. V. (org.) Estado, política e direito: políticas públicas e direitos sociais, v. 3. Criciúma: Ed. Unesc, 2011. p. 67. 
companhias seguradoras, sofrem, contudo, uma sensível diminuição de produção, pela redução do número de mineiros, ajudantes de mineiros e vagoneterios. ${ }^{51}$

A riqueza de detalhes do contexto escrito por Boa Nova Jr. encheria páginas de discussão. Neste artigo discutimos principalmente sob o ponto de vista da saúde laboral em perspectiva histórica. A primeira questão que nos chama atenção é a distinção do autor entre "verdadeiros acidentes" e "falsos acidentes", ou chamados "simuladores de acidentes". A questão levantada pelo médico suscita problemas conceituais mais de fundo, afinal, como diferenciar situações de acidentes de trabalho como verdadeiros ou falsos? Ou qual o critério social, médico ou jurídico utilizado para definir aqueles acidentes que podem ou não ser caracterizados como verdadeiros ou falsos.

O médico Boa Nova Jr. também faz menção à participação do sindicato dos mineiros no "acobertamento do acidente". Segundo ele, o operário, após ganhar alta do médico, "não se conformando com a alta compulsória que lhe é imposta pelo médico, ainda vai, por intermédio de seu sindicato, que tão bem acoberta sua simulação e seu falso acidente, bater às portas da justiça do trabalho, que, via de regra, Ihe concede sempre razão em Criciúma!"52

Essa evidência, por mais que possa ser exagerada pelo autor pela sua posição de funcionário do DNPM, demonstra que o sindicato possuía um médico e um advogado responsáveis por encaminhar os operários à justiça. Além disso, sua argumentação de que os operários batiam "às portas da justiça do trabalho", embora tratemos da justiça comum (poderia ser comum a confusão entre ambas, por se tratar de assuntos dos trabalhadores), reforça nossa hipótese de que este era um espaço muito frequentado pelos mineiros. A seguir trataremos do caso de acidente de trabalho do operário Lotério, a fim de problematizar esse assunto das chamadas "simulações de acidentes".

\section{Os operários nos processos de acidentes: exploração do trabalho ou "simulação"?}

UMA DAS FUNÇÕES que mais demandava esforço físico nas minas de carvão era dos "vagoneteiros" ou "tocadores", como eram chamados os operários responsáveis por empurrar os carros de carvão (também chamados de vagonetes) em um plano inclinado sobre trilhos de madeira. $\mathrm{Na}$ fotografia abaixo podemos ver esses trabalhadores em atividade.

51 BOA NOVA JR., op. cit., p. 84, grifos nossos.

52 Ibidem, p. 87, grifos nossos. 


\section{Fotografia 5 - Trabalhadores empurrando os "vagonetes" em mina de Criciúma, década de 1920.}

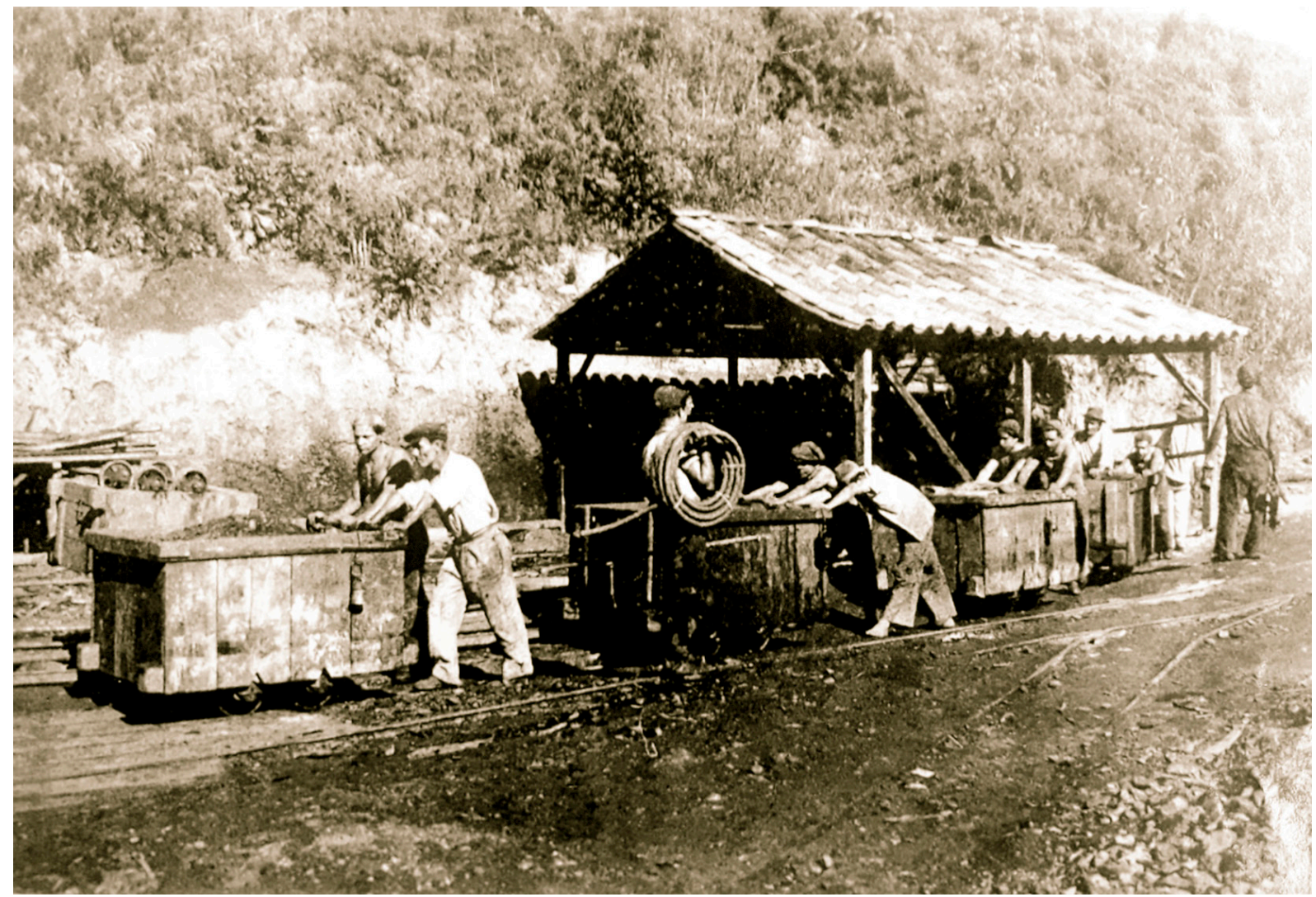

Fonte: Acervo Arquivo Histórico Municipal Pedro Milanez.

$\mathrm{Na}$ imagem vemos os "vagoneteiros" em duplas empurrarem os carros de madeira cheios de carvão, sobre trilhos de madeira. No primeiro carro o mineiro está com sapato, porém, no segundo carro o trabalhador está descalço, com os pés sobre a pirita de carvão, o que certamente ocasionava ferimentos e cortes. A função de vagoneteiro demandava um grande esforço físico pelos operários, que ocasionava uma série de acidentes e doenças profissionais: com frequência os "carros" descarrilavam, isto é, saíam fora dos trilhos de madeira velha, ocasionando diversos acidentes.

Esse esforço ocasionava uma série de acidentes e doenças profissionais: com frequência os "carros" descarrilavam, isto é, saíam fora dos trilhos de madeira velha, ocasionando diversos acidentes, como no caso do operário Lotério João Marcílio, ajudante de mineiro, 40 anos de idade, empregado da Companhia Carbonífera Boa Vista.

Lotério acidentou-se em 24 de janeiro de 1944, quando um carro carregado de carvão descarrilou e bateu no operário, conforme relata em seu depoimento: estava empurrando a "vagoneta cheia de carvão" em companhia de Manoel Santana em uma galeria íngreme, e que "ao virar o carro no cruzamento da galeria, este tombou comprimindo o depoente que estava numa valeta". 53

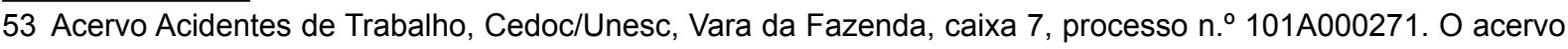


O ajudante de mineiro recebeu alta no dia 29 de março do mesmo ano do acidente; contudo, reclamou ao Ministério Público que não estava "restabelecido ainda, conforme o atestado", ${ }^{54}$ e pediu "a V. Ex. a se digne mandar o patrão manter o reclamante no seguro até que se encontre em condições de trabalhar".

O acidente do operário, ocorrido em início do ano de 1944, ainda era regido pela legislação de acidentes de 1934, pois a reforma da lei foi efetuada somente em final de 1944 e regulamentada posteriormente em 1945. Pelo Decreto n²4.637/34, a responsável por garantir a indenização e o auxílio médico ao operário em caso de acidentes de trabalho eram seguradoras privadas. A seguradora responsável pelo caso do operário Lotério era a Sul América Terrestres, Marítimos e Acidentes. Nunes da Silva, que estudou sobre as doenças e acidentes de trabalho em Salvador entre 1930 e 1940, também identificou a seguradora Sul América como responsável pelo amparo dos trabalhadores no caso de acidentes laborais.

Em um caso analisado em que o trabalhador levou uma pancada no tórax por uma lingada, ao descarregar as cargas de um navio inglês, teve uma "hemoptise, isto é, eliminação de sangue das vias aéreas por via oral" ${ }^{55}$ Ao buscar sua indenização por acidente de trabalho, o médico da seguradora negou que o acidente sofrido pelo trabalhador tivesse relação com sua incapacidade física, pois afirmou que ele já era portador de tuberculose pulmonar, e que "ele deveria buscar amparo no seu Instituto de Aposentadoria e Pensão, estando a Sul América, a partir daquele momento, descomprometida com o tratamento". ${ }^{66}$ Mas o operário não se conformou com a opinião médica da seguradora e buscou seus direitos na justiça, entrando com um processo de indenização por acidente de trabalho na justiça baiana, "buscando relacionar a tuberculose de que era portador ao trabalho que desenvolvia como carregador". ${ }^{57}$

Assim como no caso de Salvador, percebemos em Criciúma que a seguradora possuía um peso social, político e econômico nas relações locais, nas mediações entre trabalhador, empresa e justiça, constituindo mesmo uma instituição que pretendia controlar os casos de acidentes, uma vez que cabia a ela reparar o infortúnio ao assumir os riscos pelo acidente de trabalho.

No caso do operário Lotério, após a solicitação do Ministério Público que foi encaminhada ao juiz da comarca de Criciúma, este solicitou a manifestação da Seguradora Sul América sobre o acidente, sendo assim descrito o episódio pelo seu representante legal Carlos O. Seara:

Respondendo a solicitação de V.S. sobre o acidente sofrido em 24 de janeiro do ano corrente, pelo operário da Sociedade Carbonífera Boa Vista Ltda. Lotério João Marcílio, temos a informar o seguinte: Esse operário apresentou-se ao nosso médico, em 24 de janeiro, acidentado, conforme comunicação

está preservado no Centro de Memória e Documentação da Universidade do Extremo Sul Catarinense, na cidade de Criciúma, Santa Catarina.

54 Acervo Acidentes de Trabalho, Cedoc/Unesc, caixa 7, processo n. ${ }^{0} 101 \mathrm{~A} 000271$.

55 SILVA, Maria Elisa Lemos. Entre lançadeiras, guindastes e trilhos: doenças e acidentes de trabalho em Salvador nas décadas de 1930 e 1940. Mundos do Trabalho, Florianópolis, v. 7, n. 13, p. 215-231, jan.-jun. 2015, p. 215.

56 Ibidem, p. 215.

57 Ibidem, p. 216. 
feita a essa delegacia, dizendo sofrido um "mau jeito". Esteve sob tratamento médico até 9 de março, portanto 45 dias e o "mau jeito" não desaparecia, o que não deixava de ser estranho. Convencido o médico de que se tratava de um típico caso de simulação, pois havia esgotado todos os recursos, deu alta do acidente, contra a vontade de Lotério, que já sonhava com uma aposentadoria conforme anunciava, retendo em seu poder o respectivo cartão de alta, não comparecendo mais em nosso escritório. (...) O que podemos garantir a V.S. Sr. Delegado é que se trata de um elemento reconhecidamente malandro, péssimo operário, como poderá atestar o seu empregador, sendo essas informações que levaram o nosso médico a se convencer e acreditar na simulação do acidente. ${ }^{58}$

Nota-se no discurso da seguradora uma tentativa de jogar com a desqualificação moral do operário, acusando-o "típico caso de simulação", um "elemento reconhecidamente malandro", e ademais que o operário estava enganando o médico com sua simulação. Essas eram estratégias utilizadas pela seguradora para se escusar de pagar a indenização pelo acidente de trabalho. Após esse testemunho da seguradora assinado por Carlos O. Seara, seu representante legal, o juiz solicitou que o operário fosse encaminhado para perícia médica, tal como determinava a legislação.

O resultado da perícia foi descrito pelo médico como "hérnia da fossa ilíaca direita", e conclui que "diante dos resultados do exame procedido, concluo que o operário sim foi vítima de um acidente de trabalho apresentando hérnia da fossa ilíaca". E concluiu que o acidentado poderia recuperar sua capacidade de trabalho "desde que se submeta à operação da hérnia da fossa ilíaca, podendo trabalhar depois de 30 dias" ${ }^{59}$ Após a publicação do laudo médico, ainda foram ouvidas quatro testemunhas do operário, no dia 2 de julho de 1945: os trabalhadores da mina Pedro Pinto, 29 anos de idade, João José Eleutério, 27 anos de idade, Romoaldo Soares, 23 anos de idade, e Manoel Santana, 24 anos de idade, todos seus companheiros de trabalho.

As testemunhas confirmaram o acidente sofrido pelo mineiro, devido ao esforço feito pelo mesmo para segurar o carro cheio de pedra de carvão, e que o operário havia sido prensado contra a parede da galeria. Após as testemunhas serem ouvidas e o laudo médico em mãos, o juiz de Direito da comarca de Criciúma Euclydes Cerqueira Cintra convocou audiência para dar sua decisão sobre o caso:

É irrecusável o fato do paciente sofrer de uma hérnia traumática. Submetido a exame pericial, constatou-se a existência da mesma (fl. 19). Um médico em época mais próxima do acidente atestou a mesma coisa. O próprio médico da seguradora com sua própria caligrafia anotou a fls. 24 que o interessado apresentava dores lombares ao esforço (...). A prova testemunhal, como vimos, atesta o esforço feito pelo acidentado e que bem poderia ter dado causa à hérnia apresentada. Nenhuma prova fez a seguradora ou a empregadora que aludisse a produzida pelo acidentado. Apegam-se apenas a um genérico "mau jeito". Assim sendo, e tendo em vista que o acidentado exercia a atividade de ajudante de mineiro, percebia $\operatorname{Cr} \$ 16,00$ e tinha 38

58 Ibidem, p. 216.

59 Acervo Acidentes de Trabalho, Cedoc/Unesc, caixa 7, processo n $101 \mathrm{~A} 000271$. 
anos na época do acidente; atendendo que com estes dados obtém-se nas tabelas oficiais a \% de 12,45 visto como a lesão tem $n^{\circ} 326$ e o índice 3 ; julgo procedente a ação e condeno a seguradora a pagar ao acidentado Cr\$1.344,60 de juros da mora e custas. ${ }^{60}$

A decisão do juiz Euclydes Cerqueira Cintra era para o inegável fato de acidente de trabalho, tal como caracterizado pela Lei de Acidente de Trabalho. De fato, a própria lei instituía como fundamento a responsabilização do patrão pelo evento e o pagamento da indenização independentemente da demonstração de culpa, adotando a teoria do risco profissional. Cabia à companhia de mineração e à seguradora (responsável pelo pagamento da indenização) a demonstração de que o operário não havia sofrido o acidente que alegava.

$E$ foi isso que a seguradora Sul América tentou conseguir. Mesmo após decisão do juiz, a ré seguradora entrou com um agravo à ação, isto é, com recurso para o não pagamento da indenização, argumentando que se tratava de acidente ocorrido fora do trabalho, e que Lotério "não convinha ao trabalho, achava mais conveniente a percepção de dois terços de sua diária sem fazer força (...)".

Tal recurso foi rebatido pelo curador de acidentes Francisco José Rodrigues de Oliveira, que questionou veementemente a acusação de simulação de acidente por parte do operário, conforme descrevemos abaixo sua importante fala:

É de se estranhar que, nessa fase processual, procure a seguradora não reconhecer o acidente sob a denominação de mau jeito, pois foi o próprio médico da dita Cia. quem o aceitou (...). Mau jeito, bem sabem todos aqueles que vivem nesta zona carbonífera, é a denominação vulgar que o operário - esse trabalhador anônimo e honesto, porém, rude e analfabeto - dá ao sofrimento da hérnia. Que o digno representante da seguradora queira desconhecer ainda podemos admitir, visto o mesmo não ser desta região. Mas, o que não nos conformamos é a ingenuidade descabida do ilustre provisionado que defende a Cia.; ele nascido e criado na zona sulista do Estado, convivendo ao lado dos mineiros, conhecendo essa denominação vulgar, quer na vida mundana como na vida forense, pois foi antes de obter a provisão, escrevente de Cartório Civil e escrivão interino da comarca de Urussanga, venha para defesa da seguradora em causa, que, ao nosso ver, é injusta para ser ganho a Sul América, negar "algo" que sabemos conhecer de ciência própria. De mais, a seguradora nesse processo procurou por todos os meios de fugir ao seu dever; nas fls. 8 do processo, encontramos uma carta assinada pelo representante e dirigida ao Dr. Delegado Regional de Polícia, onde procura eximir-se da sua responsabilidade, tão desvaidamente (sic), a ponto de chegar a ofender ao operário acidentado com termos que negam qualquer princípio de polidez social, como sejam: "é que se trata de um elemento reconhecidamente malandro, péssimo operário". ${ }^{61}$

O relator do curador de acidentes Francisco José Rodrigues de Oliveira, no dia 24 de agosto de 1945, deu um parecer definitivo ao processo, pois posteriormente ao parecer do curador, a Procuradoria Geral do Estado, com sede em Florianópolis, confirmou a decisão do juiz de Direito ao dar causa ganha ao operário.

60 Idem

61 Acervo Acidentes de Trabalho, Cedoc/Unesc, caixa 7, processo n. ${ }^{\circ} 101 \mathrm{~A} 000271$, grifos nossos. 
O que nos chamou atenção no relato acima foi a posição adotada pelo curador de acidentes, por ser diametralmente oposta sobre a questão da simulação de acidentes adotada pela seguradora Sul América, responsável pela cobertura de acidentes dos operários da Companhia de Mineração Boa Vista. Esta, através da representação de Carlos O. Seara, foi taxativa ao chamar o operário de "malandro", "elemento avesso ao trabalho", "péssimo operário" e que estava "simulando acidente". Essa posição foi compartilhada, conforme vimos, pelo médico do Departamento Nacional de Produção Mineral Boa Nova Jr., que escreveu no seu relatório sobre os "maus jeitos", que se tratavam de "casos típicos de uma desavergonhada simulação".

A posição do curador de acidentes Francisco José Rodrigues de Oliveira é oposta ao considerar os "maus jeitos" como simulação de acidentes. Como vimos no relato, ele afirma que esse tipo de acidente de trabalho era o nome popular que os operários davam para as hérnias, causadas pelo esforço físico do trabalho. E que os "operários" eram "rudes e analfabetos", porém "honestos e anônimos". Novamente temos uma qualificação moral para os trabalhadores do carvão, nesse caso, positiva, exaltando a honestidade do sujeito e seu "anonimato", ao passo que a seguradora o qualificava como "malandro".

Ao mesmo tempo, o curador os qualifica também como "rudes" e "analfabetos", querendo justificar o uso da palavra "mau jeito" como um termo popular, que pertence ao povo, para designar a hérnia produzida pelo esforço exagerado no transporte das vagonetas de carvão.

Desse modo, temos a circularidade na utilização de uma palavra utilizada pelas classes populares, para designar uma doença causada pelo trabalho em seu excesso. Essa palavra poderia ser apropriada pela elite da sociedade com diferentes objetivos, de acordo com sua posição de classe, em defesa dos interesses patronais, ou em defesa dos trabalhadores. Os patrões, seguradora, seus representantes advogados e o médico Boa Nova Jr. a utilizavam para atacar a "simulação de acidentes", desqualificar o operário, e impor uma visão de disciplina de trabalho e do controle sobre a força de trabalho de modo que não prejudicasse seus interesses econômicos.

Do outro lado, o operário só poderia contar com sua ação na defesa do direito à indenização e de uma certa "proteção" dos magistrados, com especial destaque para a figura do curador de acidentes, incumbido pela lei e pelo Estado de resguardar os direitos dos acidentados. Hobsbawm, em seu ensaio $A$ história de baixo para cima reflete que "O fato de que uma parte e a outra é subalterna não significa que os governantes não precisam levar em conta os governados". ${ }^{62}$

62 HOBSBAWM, Eric. A história de baixo para cima. In: HOBSBAWM, Eric. Sobre história. São Paulo: Companhia das Letras, 2013. p. 294. 


\section{Considerações finais}

Neste ARTIgo demONSTROU-SE como a medicina do trabalho foi uma área que surgiu no século $\mathrm{XIX}$, voltada para diagnosticar e prevenir os acidentes e doenças laborais, visto que atingiam um grande contingente de trabalhadores, ocasionando prejuízos para a indústria e para economia. Com o fim da Primeira Guerra Mundial, a criação da OIT e explosão de greves operárias, as autoridades governamentais começaram a se preocupar com as moléstias que atingiam uma grande parcela da população. Essa preocupação, todavia, não estava somente em prevenir as doenças dos trabalhadores, mas também em evitar que essas questões se tornassem motivos para greves e paralisações da produção.

Os mineiros de carvão do sul do Brasil, em Criciúma (Santa Catarina) e São Jerônimo (Rio Grande do Sul) viviam uma realidade de trabalho de alta insalubridade e periculosidade, o que acarretava acidentes constantes e doenças profissionais que ameaçavam sua capacidade de trabalho. Para remediar essa situação e de muitas outras categorias profissionais, foram criadas leis de acidentes de trabalho que garantiam um mínimo de assistência médica, pagamento de um auxílio enquanto o trabalhador estivesse incapacitado e uma indenização. Essas leis, entretanto, criadas apenas para remediar os infortúnios dos acidentes, foram sendo mobilizadas pelos trabalhadores que reivindicavam seus direitos na justiça, reclamando aos médicos e juízes que cumprissem com suas obrigações, utilizando-se de uma retórica de justiça.

Nessa chave interpretativa, é possível supor que os operários, ao acionarem os dispositivos legais que estavam ao seu alcance criados pela legislação de acidentes, procuravam impor limites ao arbítrio dos trabalhos nas minas de carvão, deslocando para a justiça conflitos de classe que eram desfavoráveis na esfera produtiva. Para obterem êxito em suas contendas, sabiam da necessidade de constituírem alianças, seja no campo médico ou com os magistrados. Assim como a justiça, o campo médico era mais um em disputa na sociedade. Pode-se concluir neste artigo, portanto, que a medicina do trabalho constituiu-se em um importante campo de definições das doenças profissionais, particularmente no caso dessa população que vivia assombrada pelos constantes casos de acidentes e enfermidades, frutos das precárias condições de trabalho - o caso dos mineiros de carvão no sul do Brasil.

Recebido: 12/06/2020

Aprovado: 29/08/2020 